\title{
TAXATION OF PROFITS OF ORGANIZATIONS AS A REGULATOR OF MACROECONOMIC PROCESSES
}

\section{Abstract}

The article discusses the current problems in the field of profit taxation in the Russian Federation, as well as the directions for reforming the tax system adopted by the government. Considering the importance of taxes for the socioeconomic development of modern society, the state needs to implement a set of measures aimed at developing the country's economy and improving the welfare of the population.

Keywords: taxation, taxes, tax policy, tax potential, taxation system, profit, taxpayer, economic policy, economic development.

\section{References}

1. Aleksandrova M.V. Nekotorye aspekty vzaimodejstviya denezhno-kreditnogo regulirovaniya i byudzhetno-nalogovoj politiki gosudarstva v usloviyah krizisa // Ekonomika i predprinimatel'stvo. 2015. № 11 (ch. 1). P. 108 - 112.

2. Minaeva E.V. Klyuchevoe znachenie innovacionnogo potenciala dlya razvitiya organizacij v usloviyah importnoj zavisimosti strany // Ekonomika i predprinimatel'stvo. 2015. № 11 (ch. 1). P. 605 - 608.

3. Anoshina YU.F., Simonov S.YU. Optimizaciya nalogooblozheniya kak faktor aktivizacii investicionnogo processa v agroekonomike Rossii // Territoriya nauki. 2008. № 7. P. 60 - 63.

4. Panskov V.G. Nalogi i nalogooblozhenie v Rossijskoj Federacii. - M.: YUNITI, 2014.

5. Ryabova T.F., Maslyukova E.A., YUtkina O.V. Vnutrennie rezervy rosta ekonomiki strany // Ekonomika i predprinimatel'stvo. 2018. № 8 (97). P. 1310 - 1313.

6. Sidorova N.I. Sravnitel'nyj analiz naloga na pribyl' v RF i v industrial'no razvityh stranah // Finansy. 2015. № 10. P. 32-38.

7. Anoshina YU.F., Lushchik I.V. Sovershenstvovanie uchetno-analiticheskogo obespecheniya dolgosrochnyh material'nyh aktivov kommercheskih organizacij. Monografiya. Izdatel'stvo: Moskovskij universitet im. S.YU. Vitte (Moskva), 2015. $150 \mathrm{~s}$.

8. Ponomarev A.I., Ignatova T.V., Bogatyrev M.A. Nalogi i nalogovoe administrirovanie v Rossijskoj Federacii: ucheb. posobie. - 2-e izd., pererab. i dop. M: Finansy i statistika, 2009.

9. Aleksandrova M.V., Minaeva E.V. Innovacionnoe razvitie kak prioritetnoe napravlenie povysheniya konkurentosposobnosti regiona // Ekonomika i predprinimatel'stvo. 2018. №8 (97). P. 503 - 507.

\section{ЧЕЛОВЕЧЕСКИЙ КАПИТАЛ ЮГА РОССИИ В УСЛОВИЯХ ЦИФРОВИЗАЦИИ ЭКОНОМИКИ: ТРЁХКОМПОНЕНТНАЯ АНАЛИТИЧЕСКАЯ МОДЕЛЬ*}

Михалкина
Елена
Владимировна
Крячко
Виктория
Игоревна

доктор экономических наук, профессор, декан экономического факультета, Южный федеральный университет (344002, Россия, г. Ростов-на-Дону, ул. Горького, 88). E-mail: evmihalkina@sfedu.ru магистрант, экономический факультет, Южный федеральный университет (344002, Россия, г. Ростов-на-Дону, ул. Горького, 88). E-mail: vi.kryachko@mail.ru

\section{Аннотация}

В статье представлено решение проблемы накопления и эффективности использования человеческого капитала в условиях цифровизации региональной экономики. Раскрыта принципиально новая трёхкомпонентная методика анализа человеческого капитала «Источник-Механизм-Результат», позволяющая оценивать баланс между результатами реализации человеческого капитала и процессом его воспроизводства в условиях цифровизации экономики. Апробация теоретико-концептуальной авторской методики осуществлена с использованием инструментария, включающего индексный метод, эконометрический метод регрессионного и кластерного анализа на примере регионов Юга России. Результатом исследования является выявление ключевых катализаторов и ингибиторов процессов эффективного использования человеческого капитала на мезоуровне.

Ключевые слова: человеческий капитал, цифровизация экономики, регионы юга России, региональная экономика, сбалансированность развития, экономические результаты, экономические процессы интеграции, индекс развития человеческого потенциала, актор экономической системы.

\section{Введение}

$\checkmark$ современный тренд цифровизации экономики, подразумевающий широкомасштабное использование новых интегрированных технологий, рост развивающихся рынков, увеличение числа наукоёмких производств, переход к шестому технологическому укладу или к технологиям «Промышленной революции 4.0» (использование больших данных, нейротехнологий, искусственного интеллекта, промышленного интернета, робототехники и т.д.), требует углубленного понимания

\footnotetext{
* Исследование проводится при поддержке Российского фонда фундаментальных исследованиях, грант 18-010-00591 «Выбор карьерных стратегий аспирантами».
} 
взаимосвязанных процессов воспроизводства и реализации человеческого капитала в совокупности с его экономической эффективностью

$\checkmark$ авторская модель анализа человеческого капитала «Источник-Механизм-Результат» включает в себя теоретико-концептуальное понимание человеческого капитала как не статичного, а динамичного актора экономической системы, который находится в непрерывных процессах воспроизводства и использования и имеет соответствующий эффект на финансово-экономические показатели регионов юга России

$\checkmark$ выявленные факторы сбалансированности развития и эффективности реализации человеческого капитала регионов детерминируют перспективы развития регионов юга России с учётом их особенностей и максимизацией их экономических результатов в условиях цифровизации экономики.

\section{Теоретико-концептуальная модель анализа человеческого капитала регионов Юга России} в условиях цифровой экономики

В XXI веке быстрые темпы развития мировой экономики, а также информатизация и цифровизация системы экономических отношений, широкомасштабное использование новых интегрированных технологий, формирующихся на стыке цифровых, био-, когнитивных, физических технологий способствуют более глубокому изучению различных экономических процессов интеграции производства, науки, образования и последующему поиску новых подходов к решению как старых, так и совершенно новых задач, возникающих в рамках проблемы управления процессами использования человеческого капитала в целях увеличения эффективности производства.

Основополагающими факторами, предопределившими интерес к исследованию и развитию положений современной теории человеческого капитала, являются: рост развивающихся рынков, увеличение числа наукоёмких производств, переход к шестому технологическому укладу или к технологиям «Промышленной революции 4.0» (использование больших данных, нейротехнологий, искусственного интеллекта, промышленного интернета, робототехники и т.д.). Роль знаний и навыков, которыми обладают квалифицированные специалисты, в достижении экономической эффективности и производительности труда не только приобрели ключевое значение, но и продолжают оставаться базовой составляющей при дополнении новыми цифровыми технологиями, обеспечивающими принципиально иной уровень развития производительных сил общества. В этих условиях человеческий капитал, трактуемый как ресурс, позволяющий извлекать экономические выгоды, снижать трансакционные издержки, формировать новые бизнес-модели на базе новых технологий, остается объектом современной экономики труда и теории человеческого капитала.

Анализ подходов к определению капитала позволяет выделить общую для всех концепцию детерминации термина: капитал - это то, что в результате определённого преобразования имеет некоторый прирост в том или ином выражении, то есть характеризуется свойством возрастания. Во второй половине XX века Г. Беккером [1] и Т. Шульцем [2] был выделен совершенно новый вид капитала - человеческий. Согласно их подходу, человеческий капитал - это «совокупность врождённых способностей и приобретённых знаний, навыков и мотиваций». Традиционно вклад в развитие теории человеческого капитала сделали и Л. Торроу [3], М. Блауг [4], Ф. Махлуп [5], Л. Эдвинсон и М. Мэлоун [6, с. 96 - 97] и другие. Исходя из работ этих авторов человеческий капитал обобщённо может быть представлен как вид капитала, выраженный в принадлежащих человеку способностях, навыках и знаниях, которые применяются для преобразования различного рода ресурсов в блага и таким образом порождают прибавочную стоимость.

Дифференциация уровней агрегирования человеческого капитала от индивидуального до глобального представлена в работах О.В. Забелиной [7] и др., что предопределило выделение человеческого капитала семьи, отрасли, региона, федерального округа, страны в целом. С позиции управления на мезоуровне региональный и окружной уровни агрегирования человеческого капитала представляются наиболее важными.

На различных уровнях человеческий капитал анализируется также в разных структурных аспектах (образовательный, трудовой, социокультурный, капитал здоровья). В работе С.А. Грачева представлен анализ категории на региональном уровне по многокритериальному подходу по «качественным», «количественным» и «результирующим» критериям [8]. В развитие этого подхода другими авторами исследован человеческий капитал регионов через призму «воплощаемого в продукте и приносящего ренту» [9].

Другим популярным способом анализа человеческого капитала остается индекс развития человеческого потенциала [10].

В условиях перехода к цифровой экономике актуальны проблемы анализа сферы реализации человеческого капитала при тестируемом несоответствии между навыками, полученными индивидами в системе образования, и требованиями цифровой экономики [11]. Данный разрыв может 
привести к росту структурной безработицы. Возможные социальные риски и проблемы реализации человеческого капитала в цифровой экономике актуализируют развитие принципиально новых механизмов социальной поддержки в отношении экономически активного населения старших возрастов, что отмечено в исследованиях отдельных авторов [12].

Благодаря цифровизации экономики происходит сокращение трансакционных издержек, снижения затрат на сбор и обработку информации, что ведет к изменению порядка функционирования экономических систем, к трансформации бизнес-процессов с участием человеческого ресурса, тем самым изменяется и система управления. В этой связи поиск эффективных моделей взаимодействия ключевых акторов цифровой экономики является актуальной задачей. Так, основное направление реализации человеческого капитала, по мнению отдельных авторов [13], лежит через оптимизацию транзакционных издержек в сфере образования и на рынке высококвалифицированных кадров, что должно привести к более эффективному взаимодействию между ключевыми институтами цифровой экономики. Как подчеркивается в современных исследованиях [14] среди проблем реализации человеческого капитала в условиях цифровой экономики выделяют прежде всего слабый спрос на высококвалифицированный человеческий капитал, способный развивать и поддерживать экономику такого формата, а также не очень качественное предложение, которое формируется через систему образования.

Авторский подход к анализу человеческого капитала регионов в условиях цифровой экономики, предложенный в настоящей статье, основан на проведении трехкомпонентного анализа с выделением источников, механизмов и результатов использования современного человеческого капитала. Базовой гипотезой является то, что человеческий капитал предполагает непрерывное генерирование прибавочной стоимости, то есть он не может быть представлен статично, а требует рассмотрения его потокового движения в экономической системе с учетом включенности в экономические отношения, характеризующиеся новым качеством и условиями цифровой экономики. Схематично данный подход представлен на рис. 1.

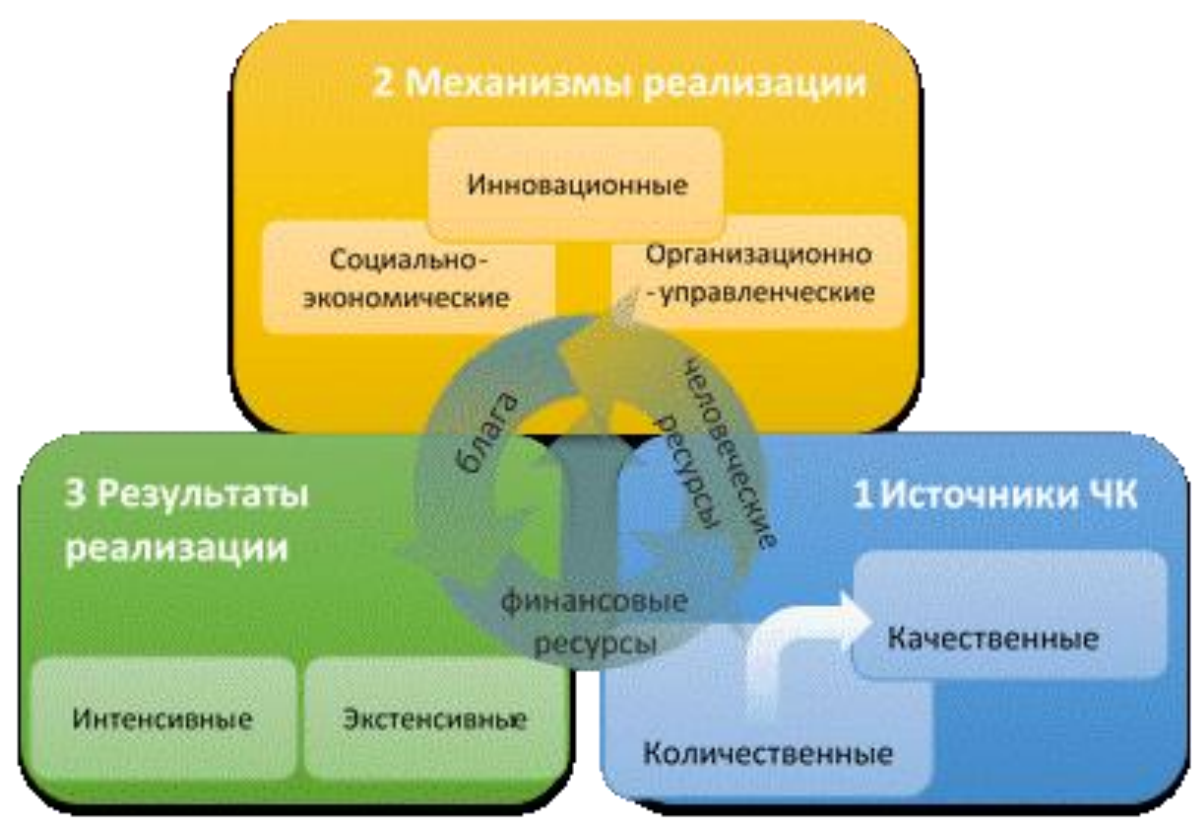

Рис. 1. Трехкомпонентная методика анализа человеческого капитала «Источник-Механизм-Результат» Источник: разработано авторами.

Основная гипотеза исследования состоит в том, что достижение высоких значений экономической результативности деятельности региона, как итога реализации человеческого капитала, возможно при высоком уровне развитости социально-экономических, организационно-управленческих и инновационных условий (цифровизации экономики), что в свою очередь невозможно без высококачественного процесса воспроизводства человеческого капитала.

Таким образом, количественные и качественные источники формирования человеческого капитала выводят на рынок труда человеческие ресурсы, соответствующие условиям цифровой экономики, обеспечивая тем самым тренды формирования нового качества производительных сил общества. Рынок труда, социально-экономические организационно-управленческие условия, а также условия цифровой экономики формируют «механизмы» реализации человеческого капитала, 
позволяющие посредством использования знаний, навыков, способностей и умений индивидов создавать материальные и нематериальные блага в новых условиях цифровизации и информатизации. Организационно-управленческие условия реализации человеческого капитала выражаются в таких критериях, как доступность образования (количество организаций начального, основного и общего среднего образования на 1000 чел.), обеспеченность больничными койками (численность населения на одну больничную койку), результативность высшего образования (удельный вес выпускников программ бакалавриата, магистратуры и специалитета, трудоустроившихся на первую работу, связанную с полученной специальностью; доля трудоустроившихся выпускников) и уровне государственно-частного партнёрства - критерии, которые напрямую отражают качество благоустройства инфраструктуры региона.

Социально-экономические условия в рамках данного авторского подхода характеризуются следующими критериями: реальные денежные доходы населения; численность населения с денежными доходами ниже величины прожиточного минимума; удельный вес аварийного жилищного фонда в общей площади всего жилищного фонда; число зарегистрированных преступлений на 100 000 человек населения; а также критерии анализа использования человеческого капитала (уровень участия в рабочей силе населения в возрасте от 15 до 72 лет. занятость населения, численность рабочей силы в возрасте от 15 до 72 лет).

Условия цифровизации экономики (инновации) позволяют оценить уровень специфического человеческого капитала, создающего основной прирост знаний. К критериям оценки условий цифровизации экономики были отнесены следующие: объем инновационных товаров, работ и услуг; доля инновационных товаров, работ и услуг; количество инновационных организаций; инновационная активность предприятий; доля инвестиций в объекты интеллектуальной собственности и численность персонала, занятого научными исследованиями и разработками.

Прибыль, получаемая в итоге потребления созданных благ, становится результатом процесса использования человеческого капитала. Результирующие реализацию человеческого капитала финансовые ресурсы поддерживают новый цикл воспроизводства человеческого капитала. Результаты, согласно авторского подхода, выражаются в интенсивных (темп роста экономики и производительность труда) и экстенсивных критериях (сальдированный финансовый результат деятельности организаций, объём ВРП, объём ВРП на душу населения).

В табл. 1 представлены критерии, по которым предлагается проводить анализ человеческого капитала регионов Юга России в рамках трехкомпонентной методики «Источник-МеханизмРезультат». Источником данных для анализа являются статистические показатели федеральной службы государственной статистики ${ }^{1}$ и официальный Интернет-портал платформы поддержки инфраструктурных проектов «РосИнфа»². Для удобства дальнейшей работы каждому критерию и подгруппе критериев присваивается условное обозначение хі, каждой группе - yi.

Таблица 1

\section{Критерии анализа человеческого капитала регионов юга России} по методике «Источник-Механизм-Результат»

\begin{tabular}{|c|c|c|}
\hline Группы & $\begin{array}{l}\text { Подгруппы } \\
\text { критериев }\end{array}$ & $\begin{array}{c}\text { Критерии анализа ЧК } \\
\text { (статистические показатели) }\end{array}$ \\
\hline 1 & 2 & 3 \\
\hline \multirow{7}{*}{$\begin{array}{l}1 \text { Источники } \\
\text { человеческого } \\
\text { капитала (y1) }\end{array}$} & \multirow{5}{*}{$\begin{array}{l}1.1 \text { Количественные } \\
\text { (х31) }\end{array}$} & 1.1.1 численность населения региона (х1) \\
\hline & & $\begin{array}{l}1.1 .2 \text { коэффициент естественного прироста на } 1000 \text { чело- } \\
\text { век населения (х2) }\end{array}$ \\
\hline & & $\begin{array}{l}1.1 .3 \text { коэффициент миграционного прироста на } 10000 \text { че- } \\
\text { ловек населения (х3) }\end{array}$ \\
\hline & & $\begin{array}{l}\text { 1.1.4 выпуск специалистов, бакалавров и магистров, тыс. } \\
\text { чел. (x4) }\end{array}$ \\
\hline & & $\begin{array}{l}\text { 1.1.5 удельный вес молодёжи в общей численности населе- } \\
\text { ния (х5) }\end{array}$ \\
\hline & \multirow[t]{2}{*}{$\begin{array}{l}1.2 \text { Качественные } \\
(x 32)\end{array}$} & $\begin{array}{l}1.2 .1 \text { ожидаемая продолжительность жизни (показатель } \\
\text { качества жизни) (х6) }\end{array}$ \\
\hline & & $\begin{array}{l}1.2 .2 \text { заболеваемость на } 1000 \text { человек (показатель каче- } \\
\text { ства здоровья) (х7) }\end{array}$ \\
\hline
\end{tabular}

\footnotetext{
1 Россия в цифрах. 2018: Крат.стат.сб. / Росстат. - М., 2018. - 522 с.

2 Платформа поддержки инфраструктурных проектов «РосИнфа» [Электронный ресурс] Режим доступа: http://www.pppi.ru/regions?region=all (дата обращения: 14.04.2019)
} 


\begin{tabular}{|c|c|c|}
\hline & & Продолжение табл. \\
\hline 1 & 2 & 3 \\
\hline \multirow[t]{18}{*}{$\begin{array}{l}2 \text { Механизмы ре- } \\
\text { ализации чело- } \\
\text { веческого капи- } \\
\text { тала (у2) }\end{array}$} & \multirow[t]{5}{*}{$\begin{array}{l}2.1 \text { Организационно- } \\
\text { управленческие } \\
\text { условия (х33) }\end{array}$} & $\begin{array}{l}2.1 .1 \text { удельный вес выпускников программ бакалавриата, } \\
\text { магистратуры и специалитета, трудоустроившихся на } \\
\text { первую работу, связанную с полученной специальностью } \\
\text { (х8) }\end{array}$ \\
\hline & & 2.1.2 доля трудоустроенных выпускников (х9) \\
\hline & & $\begin{array}{l}2.1 .3 \text { уровень развития государственно-частного партнёр- } \\
\text { ства (х10) }\end{array}$ \\
\hline & & 2.1.4 численность населения на одну больничную койку (х11) \\
\hline & & $\begin{array}{l}2.1 .5 \text { Количество организаций начального, основного и } \\
\text { общего среднего образования на } 1000 \text { чел. (х12) }\end{array}$ \\
\hline & \multirow{7}{*}{$\begin{array}{l}2.2 \text { Социально- } \\
\text { экономические } \\
\text { условия (х34) }\end{array}$} & 2.2.1 реальные денежные доходы населения (х13) \\
\hline & & $\begin{array}{l}2.2 .2 \text { численность населения с денежными доходами ниже } \\
\text { величины прожиточного минимума (x14) }\end{array}$ \\
\hline & & $\begin{array}{l}2.2 .3 \text { удельный вес аварийного жилищного фонда в общей } \\
\text { площади всего жилищного фонда (x15) }\end{array}$ \\
\hline & & $\begin{array}{l}2.2 .4 \text { число зарегистрированных преступлений на } \\
100000 \text { человек населения (х16) }\end{array}$ \\
\hline & & $\begin{array}{l}2.2 .5 \text { уровень участия в рабочей силе населения в возрасте } \\
\text { от } 15 \text { до } 72 \text { лет (х17) }\end{array}$ \\
\hline & & 2.2.6 занятость населения (х18) \\
\hline & & $\begin{array}{l}2.2 .7 \text { численность рабочей силы в возрасте от } 15 \text { до } 72 \text { лет } \\
\text { (х19) }\end{array}$ \\
\hline & \multirow{6}{*}{$\begin{array}{l}2.3 \text { Условия цифро- } \\
\text { визации экономики } \\
\text { (х35) }\end{array}$} & $\begin{array}{l}2.3 .1 \text { объём инновационных товаров, работ и услуг, млн. } \\
\text { руб. (х20) }\end{array}$ \\
\hline & & $\begin{array}{l}2.3 .2 \text { объём инновационных товаров, работ и услуг в \% от } \\
\text { общего объёма отгруженных товаров, работ и услуг (х21) }\end{array}$ \\
\hline & & $\begin{array}{l}2.3 .3 \text { количество организаций, выполнявших научные ис- } \\
\text { следования и разработки (х22) }\end{array}$ \\
\hline & & 2.3.4 инновационная активность предприятий (х23) \\
\hline & & $\begin{array}{l}2.3 .5 \text { доля инвестиций в объекты интеллектуальной соб- } \\
\text { ственности (х24) }\end{array}$ \\
\hline & & $\begin{array}{l}2.3 .6 \text { численность персонала, занятого научными исследо- } \\
\text { ваниями и разработками (х25) }\end{array}$ \\
\hline \multirow{5}{*}{$\begin{array}{l}3 \text { Результаты } \\
\text { реализации че- } \\
\text { ловеческого ка- } \\
\text { питала (у3) }\end{array}$} & \multirow[t]{3}{*}{$\begin{array}{l}3.1 \text { Экстенсивные } \\
(\mathrm{x} 36)\end{array}$} & $\begin{array}{l}3.1 .1 \text { сальдированный финансовый результат деятельно- } \\
\text { сти организаций (х26) }\end{array}$ \\
\hline & & 3.1 .2 объём валового регионального продукта (х27) \\
\hline & & 3.1 .3 объём ВРП на душу населения (х28) \\
\hline & \multirow{2}{*}{$\begin{array}{l}3.2 \text { Интенсивные } \\
\text { (х37) }\end{array}$} & 3.2.1 темп роста ВРП (х29) \\
\hline & & 3.2 .2 индекс производительности труда (х30) \\
\hline
\end{tabular}

Источник: Составлено авторами

Анализ человеческого капитала регионов Юга России предполагается проводить двумя способами.

В соответствии с первым способом по каждому критерию, подгруппе и группе критериев методики «Источник-Механизм-Результат» рассчитываются индексы.

Во втором случае на основании рассчитанных индексов строится система координат регионов, позволяющая произвести качественную интерпретацию полученных индексов.

Второй способ предполагает проведение кластерного анализа регионов методом иерархической кластеризации и кластеризации методом К-средних по всем представленным критериям в рамках каждой группы «Источники», «Механизмы» и «Результаты».

\section{Индексный метод в анализе человеческого капитала регионов юга России по методике «Источник-Механизм-Результат»}

Категория человеческого капитала является сложной, включает в себя множество параметров. Построение комплексных индексов является целесообразным при попытке дать оценку человеческому капиталу, и особенно при проведении анализа на макроуровне. Поэтому одним из вариантов проведения анализа человеческого капитала юга России по методике «Источник-МеханизмРезультат» был выбран именно нестоимостной индексный метод. 
Авторы предполагают, что критерии группы «Механизмы» имеют неодинаковое влияние на результативные показатели реализации человеческого капитала. Для проверки данной гипотезы, а также последующего определения весовых коэффициентов при вычислении общих индексов группы и подгруппы критериев, строится уравнение регрессии. Ввиду того, что в группе «Механизмы» 17 критериев, что превышает количество исследуемых объектов (15 регионов), целесообразно провести отдельную оценку влияния критериев подгрупп группы «Механизмы» на общий индекс группы «Результаты». Итоговые уравнения имеют вид (формула (1) по подгруппе организационноуправленческих условий, формула (2) - по подгруппе социально-экономических условий и формула (3) - по подгруппе условий цифровизации экономики):

$$
\begin{aligned}
& y_{\mathbf{b}}=-0,37 x_{\mathbf{g}}+0,51 x_{\mathbf{g}}-0,4 x_{1 \mathbf{2}}+0,47, \\
& y_{\mathbf{3}}=-0,5 x_{17}+0,53 x_{1 \mathbf{g}}+0,34 x_{1 \mathbf{9}}+0,28 \\
& y_{\mathbf{b}}=0,58 x_{2 \mathbf{1}}+0,29 .
\end{aligned}
$$

$\begin{array}{cc}\text { Multiple R } & \text { F } \\ 0,707 & 3,66 \\ 0,780 & 5,72 \\ 0,580 & 6,60\end{array}$

где значения хі и уі соответствуют указанным в табл. 1. Качество регрессионных уравнений высокое, так как коэффициент детерминации имеет значение выше 0,5, значение F-критерия Фишера во всех случаях больше табличного, что свидетельствует о статистической значимости и надёжности уравнений регрессии.

На основании полученного уравнения регрессии экспертно присваиваются весовые коэффициенты критериям в общих индексах подгрупп организационно-управленческих, социальноэкономических и инновационных критериев (формулы (4)-(6)).

$$
\begin{aligned}
& x_{3 \mathbf{3}}=0,24 x_{\mathbf{g}}+0,4 x_{9}+0,05 x_{10}+0,05 x_{1 \mathbf{1}}+0,26 x_{12} ; \\
& x_{3 \mathbf{4}}=0,05 x_{13}+0,05 x_{14}+0,05 x_{15}+0,05 x_{16}+0,29 x_{17}+0,31 x_{18}+0,2 x_{19} ; \\
& x_{35}=0,1 x_{20}+0,5 x_{21}+0,1 x_{22}+0,1 x_{23}+0,1 x_{24}+0,1 x_{24}
\end{aligned}
$$

Полученные индексы х33-х35 составляют общий индекс группы «Механизмы» реализации человеческого капитала, коэффициенты которого также определяются при помощи регрессионного уравнения, оценивающего влияние общих индексов подгрупп х33-х35 на «Результаты» реализации человеческого капитала. В данном случае уравнение регрессии имеет вид (формула (7)):

$$
y_{3}=0,58 x_{35}+0,27 \text {. }
$$

Полученное уравнение регрессии статистически значимо и надёжно: коэффициент детерминации составил 0,579, значение F-критерия Фишера - 6,57. Так как х33 и х34 не вошли в регрессионное уравнение, имеются достаточные основания полагать, что факторы условий цифровизации экономики группы «механизмов» реализации человеческого капитала в наибольшей степени влияют на результаты реализации человеческого капитала. Следовательно, общий индекс группы «Механизмы» реализации человеческого капитала будет иметь вид (формула (8)):

$$
y_{\mathbf{z}}=0,2 x_{3 \mathbf{3}}+0,2 x_{34}+0,6 x_{35} \text {. }
$$

Аналогичным образом вычисляются индексы подгрупп качественных и количественных критериев группы «Источники» человеческого капитала. Уравнение регрессии, оценивающее влияние всех критериев группы «Источники» человеческого капитала на общий индекс группы критериев «Механизмов», имеет вид (формула (9) - для подгруппы количественных источников человеческого капитала; формула (10) - для подгруппы качественных):

$$
\begin{array}{lll}
y_{\mathbf{2}}=0,79 x_{\mathbf{1}}-0,32 x_{\mathbf{5}}+0,26 . & \text { Multiple R } & \mathrm{F} \\
y_{\mathbf{2}}=-0,42 x_{\mathbf{6}}-0,32 x_{7}+0,52 . & 0,907 & 27,85 \\
& 0,532 & 2,37
\end{array}
$$

На основании полученного регрессионного уравнения, имеющего достаточную статистическую значимость и надёжность, экспертно назначаются весовые коэффициенты при расчёте индексов подгрупп количественных и качественных источников человеческого капитала (формулы (1112) соответственно).

$$
\begin{aligned}
& x_{31}=0,55 x_{1}+0,05 x_{2}+0,05 x_{3}+0,05 x_{4}+0,3 x_{5} \\
& x_{32}=0,55 x_{6}+0,45 x_{7}
\end{aligned}
$$

Полученные индексы х31-х32 составляют общий индекс группы «Источники» человеческого капитала, коэффициенты которого также определяются при помощи регрессионного уравнения, 
оценивающего влияние общих индексов подгрупп х31-х32 на «Механизмы» реализации человеческого капитала. В данном случае уравнение регрессии имеет вид (формула (13)):

$$
y_{\mathbf{2}}=0,53 x_{31}-0,51 x_{32}+0,35 \text {. }
$$

Полученное уравнение регрессии статистически значимо и надёжно: коэффициент детерминации составил 0,751, значение F-критерия Фишера - 7,76. Очевидно большая степень влияния количественных источников человеческого капитала на «механизмы» реализации человеческого капитала. Поэтому формула для расчёта общего индекса группы «источники» человеческого капитала будет иметь вид (формула (14)):

$$
y_{1}=0,75 x_{31}+0,25 x_{32} \text {. }
$$

Рассчитанные по описанной выше методике индексы групп и подгрупп критериев анализа человеческого капитала для каждого региона приведены в табл. 2.

Таблица 2

\section{Индексы групп и подгрупп критериев анализа человеческого капитала регионов

\begin{tabular}{|c|c|c|c|c|c|c|c|c|c|c|}
\hline & \multicolumn{3}{|c|}{ Источники ЧК } & \multicolumn{4}{|c|}{ Механизмы реализации ЧК } & \multicolumn{3}{|c|}{$\begin{array}{c}\text { Результаты реа- } \\
\text { лизации ЧК }\end{array}$} \\
\hline & $\begin{array}{l}\text { Коли- } \\
\text { че- } \\
\text { ствен- } \\
\text { ные }\end{array}$ & $\begin{array}{l}\text { Каче- } \\
\text { ствен- } \\
\text { ные }\end{array}$ & $\begin{array}{l}\text { Общий } \\
\text { индекс } \\
\text { группы }\end{array}$ & $\begin{array}{l}\text { Организа- } \\
\text { ционно- } \\
\text { управлен- } \\
\text { ческие } \\
\text { условия }\end{array}$ & \begin{tabular}{|l} 
Соци- \\
ально- \\
эконо- \\
миче- \\
ские \\
условия
\end{tabular} & $\begin{array}{l}\text { Условия } \\
\text { цифро- } \\
\text { визации } \\
\text { эконо- } \\
\text { мики }\end{array}$ & $\begin{array}{l}\text { Общий } \\
\text { индекс } \\
\text { группы }\end{array}$ & $\begin{array}{l}\text { Экс- } \\
\text { тен- } \\
\text { сив- } \\
\text { ные }\end{array}$ & $\begin{array}{l}\text { Ин- } \\
\text { тен- } \\
\text { сив- } \\
\text { ные }\end{array}$ & $\begin{array}{c}\text { Общий } \\
\text { индекс } \\
\text { груп- } \\
\text { пы }\end{array}$ \\
\hline $\begin{array}{l}\text { Республика } \\
\text { Ингушетия }\end{array}$ & 0,37 & 0,84 & 0,48 & 0,35 & 0,45 & 0,08 & 0,21 & 0,01 & 0,07 & 0,04 \\
\hline $\begin{array}{l}\text { Республика } \\
\text { Дагестан }\end{array}$ & 0,65 & 0,38 & 0,58 & 0,35 & 0,36 & 0,08 & 0,19 & 0,21 & 0,44 & 0,32 \\
\hline $\begin{array}{l}\text { Карачаево- } \\
\text { Черкесская } \\
\text { Республика }\end{array}$ & 0,16 & 0,45 & 0,23 & 0,41 & 0,12 & 0,02 & 0,12 & 0,08 & 0,69 & 0,39 \\
\hline $\begin{array}{l}\text { Кабардино- } \\
\text { Балкарская } \\
\text { Республика } \\
\end{array}$ & 0,27 & 0,67 & 0,37 & 0,29 & 0,46 & 0,08 & 0,20 & 0,09 & 0,58 & 0,33 \\
\hline $\begin{array}{l}\text { Республика } \\
\text { Северная Осетия- } \\
\text { Алания } \\
\end{array}$ & 0,21 & 0,30 & 0,23 & 0,25 & 0,33 & 0,05 & 0,15 & 0,12 & 0,16 & 0,14 \\
\hline $\begin{array}{l}\text { Чеченская } \\
\text { Республика }\end{array}$ & 0,43 & 0,54 & 0,46 & 0,28 & 0,42 & 0,12 & 0,21 & 0,04 & 0,70 & 0,37 \\
\hline $\begin{array}{l}\text { Ставропольский } \\
\text { край }\end{array}$ & 0,44 & 0,39 & 0,43 & 0,53 & 0,50 & 0,43 & 0,46 & 0,33 & 0,30 & 0,31 \\
\hline $\begin{array}{l}\text { Республика } \\
\text { Калмыкия } \\
\end{array}$ & 0,08 & 0,23 & 0,12 & 0,59 & 0,42 & 0,14 & 0,29 & 0,14 & 0,23 & 0,18 \\
\hline $\begin{array}{l}\text { Волгоградская } \\
\text { область }\end{array}$ & 0,31 & 0,28 & 0,30 & 0,70 & 0,50 & 0,27 & 0,40 & 0,38 & 0,37 & 0,37 \\
\hline $\begin{array}{l}\text { Краснодарский } \\
\text { край }\end{array}$ & 0,65 & 0,27 & 0,56 & 0,60 & 0,72 & 0,87 & 0,78 & 1,00 & 0,40 & 0,70 \\
\hline г. Севастополь & 0,14 & 0,42 & 0,21 & 0,18 & 0,38 & 0,21 & 0,24 & 0,07 & 1,00 & 0,54 \\
\hline $\begin{array}{l}\text { Астраханская } \\
\text { область }\end{array}$ & 0,19 & 0,34 & 0,23 & 0,60 & 0,59 & 0,16 & 0,33 & 0,42 & 0,65 & 0,54 \\
\hline $\begin{array}{l}\text { Республика } \\
\text { Адыгея }\end{array}$ & 0,12 & 0,27 & 0,15 & 0,26 & 0,20 & 0,33 & 0,29 & 0,14 & 0,61 & 0,37 \\
\hline Ростовская область & 0,54 & 0,06 & 0,42 & 0,60 & 0,60 & 0,70 & 0,66 & 0,53 & 0,60 & 0,57 \\
\hline Республика Крым & 0,21 & 0,37 & 0,25 & 0,52 & 0,46 & 0,11 & 0,26 & 0,19 & 0,92 & 0,55 \\
\hline
\end{tabular} Юга России в рамках схемы «Источники-механизмы-результаты»}

Источник: составлено авторами.

Как видно из данных табл. 2, наивысшие значения индексов в группах критериев «Механизмы» и «Результаты» имеют Краснодарский край и Ростовская область. Также в тройку лидеров по группе «Источники» человеческого капитала вошли республики Дагестан и Ингушетия, по группе 
«Механизмы» реализации человеческого капитала - Ставропольский край, по группе «Результаты» - республика Крым.

Особенностями данного метода являются: 1) весовые коэффициенты входящих в индексы критериев анализа человеческого капитала юга России статистически обоснованы; 2) индексы носят относительный характер.

Таким образом, в данной части статьи была подробна приведена методика построения индексов человеческого капитала по схеме «Источник-механизм-результат» при помощи методов регрессионного анализа и методики, применяемой при построении Индекса развития человеческого потенциала. Полученные результаты (индексы регионов) интерпретируются в следующей части статьи при построении системы координат человеческого капитала регионов юга России.

\section{Система координат человеческого капитала регионов юга России по методике «Источник-Механизм-Результат»}

Построение системы координат человеческого капитала регионов Юга России позволяет наглядно оценить сбалансированность взаимодействия источников, механизмов и результатов реализации человеческого капитала (рис. 2).

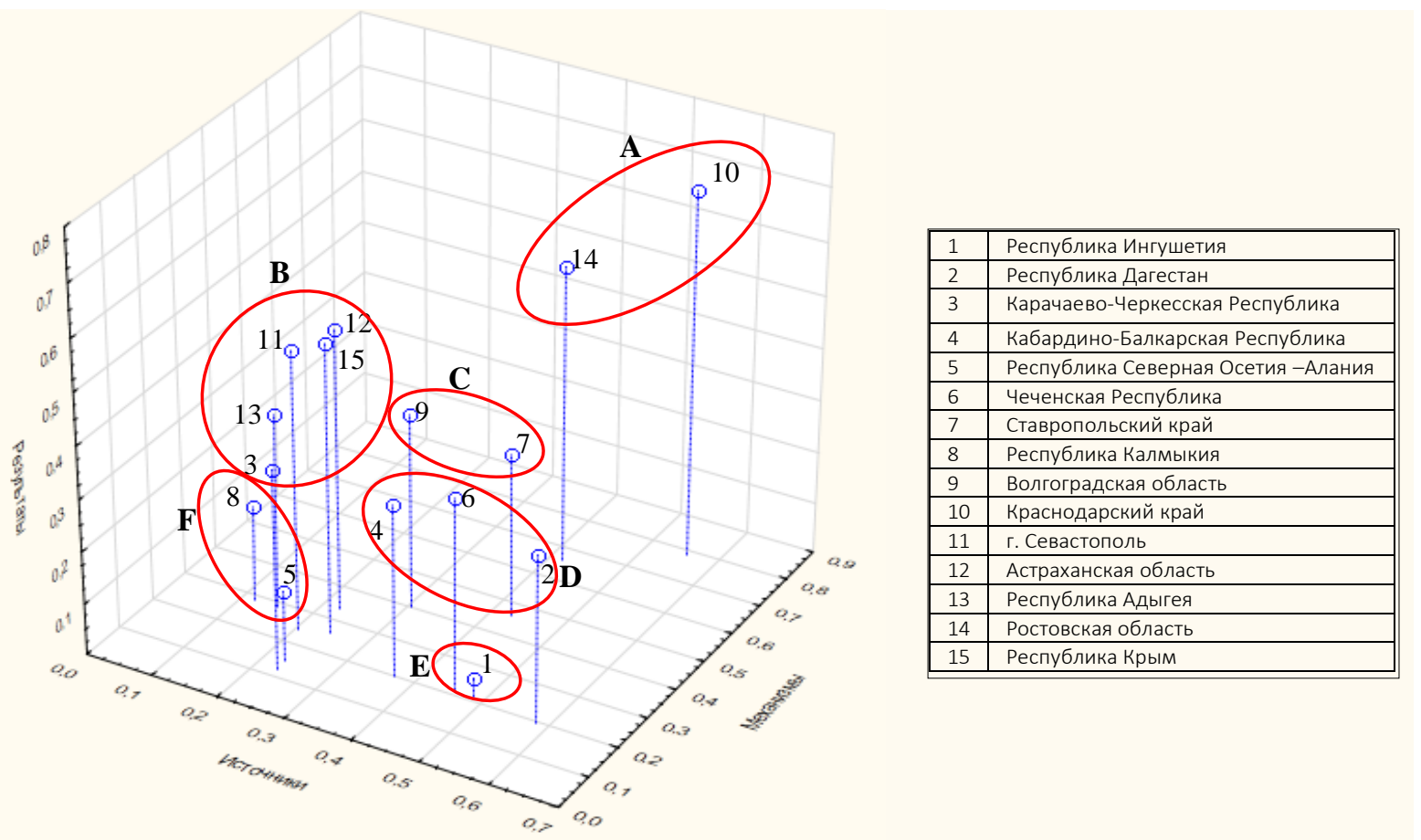

Рис. 2. Координаты регионов Юга России по соотношению индексов «Источник»-«Механизм» Источник: Разработано авторами реализации человеческого капитала

Наибольшую сбалансированность и наивысшие результаты по использованию человеческого капитала имеет Краснодарский край и Ростовская область (групп «А»). Сбалансированность структуры цикла реализации человеческого капитала Ростовской области несколько уступает первому региону по источникам человеческого капитала. Приблизительно однородную структуру цикла реализации человеческого капитала и средние значения индексов имеют регионы, образующие выделенную на графике группу «В» (Карачаево-Черкесская республика, республики Адыгея и Крым, Астраханская области и г. Севастополь). Регионы данной группы отличаются по группе «Результатов»: имеют значения несколько выше средних. В группу «С» вошли Ставропольский край и Волгоградская области - регионы с одинаково невысокими значениями индексов механизмов и результатов реализации человеческого капитала. Группу «D» составили республика Дагестан, Чеченская и Кабардино-Балкарская республики. Эти регионы имеют высокие значения группы «Источники», но достаточно низкие значения индексов по группе «Механизмы». Особое положение занимает Ингушетия (группа «Е») - в регионе очень высокое значение индекса источников человеческого капитала и крайне низкие значения индексов результатов реализации человеческого капитала, значения индекса по группе «Механизмы» также не очень высоко. Группу «F» составили такие республики, как Северная Осетия-Алания и Калмыкия. Отличительной особенностью данной группы являются низкие значения по всем индексам. 
Таким образом, визуализация рассчитанных индексов человеческого капитала по авторской методике «Источники-Механизмы-Результаты» позволила выявить определённые закономерности распределения регионов Юга России в данной системе координат и проанализировать сбалансированность структуры цикла реализации человеческого капитала. Для подтверждения проведённого анализа путём построения системы координат целесообразно провести кластерный анализ регионов по критериям источников, механизмов и результатов реализации человеческого капитала.

Кластеризация регионов Юга России по критериям анализа человеческого капитала в рамках трехкомпонентной методики «Источник-Механизм-Результат»

Применение метода иерархической кластеризации позволило получить результаты, представленные на рис. 3, в значительной мере подтверждающие полученное в предыдущей части распределение регионов относительно распределения регионов по классам в рамках групп факторов авторского подхода анализа человеческого капитала мезоуровня. На рис. 3 красной пунктирной линией отмечены полученные кластеры, сформированные по всей совокупности критериев анализа человеческого капитала регионов Юга России.

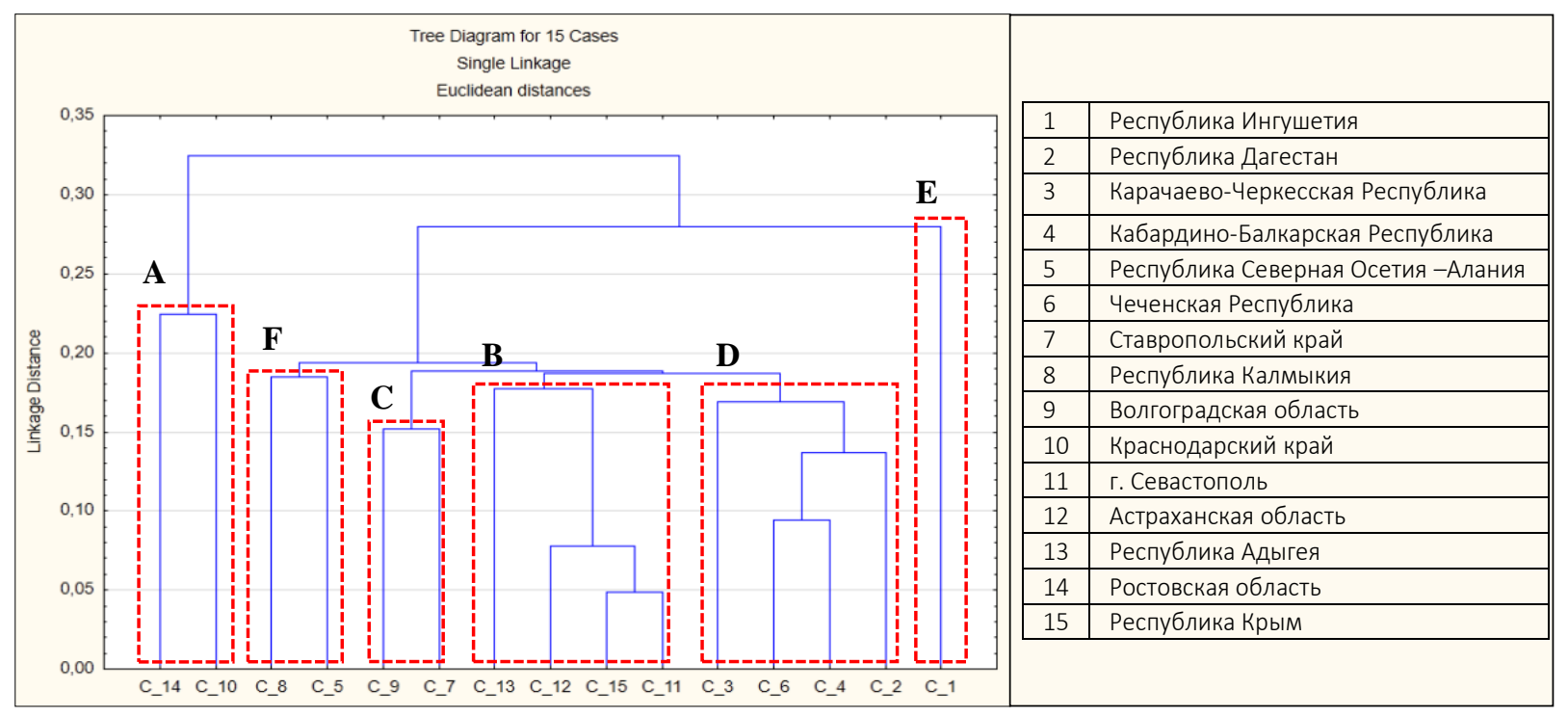

Рис. 3. Иерархическая кластеризация регионов Юга России по индексам всех групп «Источники», «Механизмы», «Результаты» реализации человеческого капитала

Источник: Разработано авторами

Согласно методу иерархической кластеризации, получено 6 кластеров, которые почти полностью подтвердили полученные в системе координат группы регионов. К классу «А», так же, как и при визуализации индексов в трёх мерном пространстве, отнеслись Ростовская область и Краснодарский край, регионы с очень высокими значениями индексов. В класс «В» вошли республики Адыгея и Крым, Астраханская области и г. Севастополь. Данные регионы имеют высокие значения индексов человеческого капитала. Класс «С» составили Ставропольский край и Волгоградская область, обладающие достаточно однородной структурой человеческого капитала по схеме «Источник-механизм-результат». Класс - «D», к которому относятся Карачаево-Черкесская, КабардиноБалкарская, Чеченская республики, республики Дагестан. Эти регионы отличаются средними значениями по группе «Результаты», низкими значениями по группе «Механизмы» и высокими значениями по группе «Источники». Совершенно отдельно от всех значится республика Ингушетия и входит в класс «Е». Республики Северная Осетия-Алания и Калмыкия выделились в класс «F», регионы обладают низкими значениями индексов по всем трём группам.

С целью определения внутренней сбалансированности человеческого капитала регионов Юга России по трёхкомпонентной методике «Источник-Механизм-Результат» проводится кластеризация регионов методом К-средних, который позволяет получить распределение объектов по заранее заданному количеству классов. Целесообразно выделить 4 класса:

- 1 класс - очень высокие значения критериев человеческого капитала;

- 2 класс - высокие значения критериев человеческого капитала;

- 3 класс - низкие значения критериев человеческого капитала;

- 4 класс - очень низкие значения критериев человеческого капитала.

Результаты кластеризации методом К-средних приведены в табл. 3. 


\section{Результаты кластеризации регионов Юга России отдельно по каждой группе критериев} анализа человеческого капитала методом К-средних

\begin{tabular}{|c|c|c|c|c|}
\hline \multirow[t]{2}{*}{ Регионы юга России } & \multicolumn{3}{|c|}{$\begin{array}{c}\text { Распределение в группах } \\
\text { по кластерам (номера кластеров) }\end{array}$} & \multirow{2}{*}{$\begin{array}{l}\text { Уровни сбалансирован- } \\
\text { ности структуры челове- } \\
\text { ческого капитала }\end{array}$} \\
\hline & Источники & Механизмы & Результаты & \\
\hline Республика Ингушетия & 1 & 4 & 4 & $2 \mathrm{~b}$ \\
\hline Республика Дагестан & 1 & 3 & 2 & $2 \mathrm{~b}$ \\
\hline Карачаево-Черкесская Республика & 4 & 3 & 3 & $1 \mathrm{a}$ \\
\hline Кабардино-Балкарская Республика & 4 & 3 & 3 & $1 \mathrm{a}$ \\
\hline Республика Северная Осетия-Алания & 4 & 3 & 4 & $1 \mathrm{~b}$ \\
\hline Чеченская Республика & 1 & 3 & 3 & $2 \mathrm{~b}$ \\
\hline Ставропольский край & 4 & 2 & 2 & $2 \mathrm{a}$ \\
\hline Республика Калмыкия & 4 & 3 & 4 & $1 \mathrm{~b}$ \\
\hline Волгоградская область & 4 & 2 & 2 & $2 \mathrm{a}$ \\
\hline Краснодарский край & 3 & 1 & 1 & $2 \mathrm{a}$ \\
\hline г. Севастополь & 2 & 3 & 3 & $1 \mathrm{~b}$ \\
\hline Астраханская область & 4 & 2 & 4 & $2 \mathrm{~b}$ \\
\hline Республика Адыгея & 4 & 3 & 3 & $1 \mathrm{a}$ \\
\hline Ростовская область & 3 & 1 & 2 & $2 \mathrm{~b}$ \\
\hline Республика Крым & 2 & 3 & 3 & $1 \mathrm{~b}$ \\
\hline
\end{tabular}

Источник: Составлено авторами

По итогам кластеризации выделены три основных уровня сбалансированности структуры человеческого капитала по авторской методике «Источник-Механизм-Результат» и три дополнительных.

Первый основной уровень - сбалансированные значения критериев человеческого капитала по всем группам трёхкомпонентной схемы «Источник-Механизм-Результат». Абсолютно сбалансированных регионов, которые попали бы по всем группам в один кластер, по настоящим данным нет. Поэтому первый уровень сбалансированности имеют регионы, которые дважды попали в один и тот же кластер, а по третьему кластеру разница с двумя другими не более, чем на один класс. Второй основной уровень предполагает наличие разницы не более чем, в два кластера либо разницу в три кластера, либо одновременное распределение по трём разным кластерам.

Базовая логика присвоения дополнительных уровней состоит в том, что для более эффективной реализации человеческого капитала при разнородности основных кластеров желательно, чтобы кластер каждой последующей группы трёхкомпонентной методики «Источник-МеханизмРезультат» был выше предыдущего:

а - кластер группы «Механизмы» не ниже группы «Источники» и/или кластер группы «Результаты» не ниже группы «Механизмы»;

b - кластер группы «Механизмы» ниже группы «Источники», кластер группы «Результаты» ниже группы «Механизмы», а также случай одновременной разнонаправленности (табл. 4).

Таблица 4

Распределение регионов по уровням сбалансированности

\begin{tabular}{|l|l|l|}
\hline & 1 Сбалансированная структура & 2 Несбалансированная структура \\
\hline а эффективный баланс & $\begin{array}{l}\text { Республика Адыгея } \\
\text { Карачаево-Черкесская Республика, } \\
\text { Кабардино-Балкарская Республика, }\end{array}$ & $\begin{array}{l}\text { Ставропольский край, } \\
\text { Краснодарский край, } \\
\text { Волгоградская область, }\end{array}$ \\
\hline b неэффективный баланс & $\begin{array}{l}\text { Республика Северная Осетия-Алания, } \\
\text { Республика Калмыкия, } \\
\text { Г. Севастополь, } \\
\text { Республика Крым }\end{array}$ & $\begin{array}{l}\text { Республика Ингушетия, } \\
\text { Республика Дагестан, } \\
\text { Чеченская Республика, } \\
\text { Астраханская область, } \\
\text { Ростовская область }\end{array}$ \\
\hline
\end{tabular}

Примечание: Составлено авторами

Несмотря на невысокие значения индексов, республика Адыгея, Карачаево-Черкесская и Кабардино-Балкарская республики, имеют достаточно сбалансированную и эффективную структуру «Источник-Механизм-Результат»: регионы попали в кластер 4 с очень низкими значениями по группе «Источники», но по другим двум группам вошли в кластер 3, то есть, несмотря на слабые источники человеческого капитала, механизмы его реализации работают нормально и дают соответ- 
ствующие результаты. Ставропольский и Краснодарский края, а также Волгоградская область имеют большой разрыв между значениями индексов источников человеческого капитала и механизмами и результатами его реализации. Однако данный дисбаланс эффективный, так как показатели последних двух групп одни из самых высоких.

Стоит отметить, что основными классифицирующим признаком по группе «Источники» человеческого капитала в результате проведения процедуры кластеризации стал естественный прирост населения, что определило главенствующее положение многих республик Северного Кавказа в данной группе и ухудшило положение регионов с хорошими показателями групп «Механизмы» и «Результаты» в данной матрице сбалансированности регионов.

Республики Крым, Калмыкия и Северная Осетия-Алания, а также г. Севастополь сбалансированы, но результаты и/или механизмы реализации человеческого капитала работают хуже источников, что в значительной мере может тормозить развитие региона.

Наконец, республики Ингушетия, Дагестан, Чеченская республика, Астраханская и Ростовская области имеют несбалансированные структуры и их дисбаланс неэффективен. В данном случае пограничное положение имеет Ростовская область, так как по группе «Результаты» реализации человеческого капитала регион очень близок к положению Краснодарского края.

\section{Заключение}

Проведённый анализ человеческого капитала по авторской трёхкомпонентной методике «Источник-Механизм-Результат» позволяет частично подтвердить выдвинутую в начале исследования гипотезу. Действительно, именно высокий уровень развития механизмов реализации человеческого капитала способствует достижению высоких результирующих значений экономической деятельности региона. Однако, исследование показало, что высокий уровень развития источников человеческого капитала не обеспечивает ни высоких показателей механизмов, ни высоких показателей результатов, а высокие показатели миграционного и естественного прироста населения тормозят процессы цифровизации экономики.

По результатам исследования доступны также и другие выводы.

Во-первых, человеческий капитал не является статичным, что формирует потенциал для его анализа в динамике модели от источника к результату.

Во-вторых, регрессионный анализ показал, что высокие результаты деятельности региона возможно за счёт эффективного функционирования прежде всего основных (инновационных) условий цифровизации экономики. На эффективную работу механизмов реализации человеческого капитала оказывают влияние численность населения региона и доля молодёжи в структуре населения.

В-третьих, индексный метод и визуализация объектов исследования в трёхмерном пространстве позволили выявить принципиальных лидеров по реализации человеческого капитала: Ростовская область и Краснодарский край - регионы с высоким потенциалом развития цифровизации экономики. При этом наблюдается устойчивая склонность к крайностям: регионы с развитой инфраструктурой и значительными результирующими показателями деятельности, имеют слабые источники человеческого капитала, живущие за счёт миграции населения, а регионы с большим естественным приростом населения практически не развиваются в сфере цифровизации экономики.

В-четвертых, регионы с невысокими значениями индексов, как правило, имеют более сбалансированную структуру процесса реализации человеческого капитала.

Таким образом, высокие результаты реализации человеческого капитала возможны за счёт:

- большой численности населения с умеренным естественным и миграционным уровнем прироста, значительной доле молодёжи среди всего населения;

- качественных организационно-управленческих условий в области системы образования (количество школ, эффективное трудоустройство выпускников вузов);

- высоких показателях занятости населения;

- развитых механизмах создания инноваций (в частности, большой доле инновационных товаров, работ и услуг в общем объёме отгруженных товаров, работ и услуг).

\section{Литература}

1. Becker G.S. Investment in Human Capital: A Theoretical Analysis//Journal of Political Economy, Vol.70, No.5, Part 2, 1962, pp.9-49

2. Shultz T. Human Capital in the International Encyclopedia of the Social Sciences. - N.Y., 1968. - Vol. 6.

3. Thurow L. (1970). Investment in Human Capital, Belmont. P. 1-15, 104.

4. Blaug, M. (1970). An Introduction to the Economics of Education. L. P. 19

5. Machlup F. (1984). The Economics of Information and Human Capital. Princeton. 201-203 P.

6. Эдвисон Л., Мэлоун М. Интеллектуальный капитал. Определение истинной стоимости компании // Новая постиндустриальная волна на Западе. Антология. - М.: Academia, 1999. 
7. Забелина О.В., Козлова Т.М., Романюк А.В. Человеческий капитал региона: проблемы сущности, структуры и оценки // Статистика и экономика. 2013. №4.

8. Грачев С. А. Оценка величины человеческого капитала регионов на основе многокритериального подхода // Вопросы управления. 2018. №2 (32). С. 46 - 53.

9. Аничин В.Л., Дорофеев А.Ф., Ващейкина Ю.Ю. Стоимостная оценка человеческого капитала // Научные ведомости Белгородского государственного университета. Серия: Экономика. Информатика. 2017. 43. № 16 (265). С. 90 - 96.

10.Сахарова О.Н. Индекс развития человеческого потенциала: место России в современном мире // Вестник ТИУиЭ. 2014. №1 (19). С. 16 - 20.

11.Питайкина И.А., Влазнева С.А. Формирование нового качества человеческого капитала в условиях цифровой экономики // Вопросы экономики и права. 2018. №7.С. 39 - 44.

12.Шибаева H.A., Евдокимова О.В. Повышение функциональной активности человеческого капитала в цифровой экономике // Управление инновациями / материалы междунар. науч.-практич. конф. Новочеркасск: Изд-во ЮРГПУ (НПИ) им. М.И. Платова, 2018. С. 71 - 76.

13.Дятлов C.A., Доброхотов М.A. Формы реализации человеческого капитала в цифровой экономике // Известия Санкт-Петербургского государственного экономического университета. 2018. № 4. С. 25 - 28.

14.Кельчевская Н.P., Ширинкина E.В. Особенности управления человеческим капиталом на предприятиях в условиях цифровой экономики // Инновации в менеджменте. 2018. № 4(18). С. 24 - 31.

Mikhalkina Elena Vladimirovna, Doctor of Economic sciences, Professor, Dean of Economic Theory Faculty, Southern Federal University (88, Gorky st., Rostov-on-Don, 344002, Russian Federation). E-mail: evmihalkina@sfedu.ru.

Kryachko Victoria Igorevna, Postgraduate of Department of Economic Theory, Southern Federal University (88, Gorky st., Rostov-on-Don, 344002, Russian Federation).E-mail: vi.kryachko@mail.ru

\section{THE HUMAN CAPITAL OF THE SOUTH OF RUSSIA IN THE CONDITIONS OF DIGITALIZATION OF ECONOMY: THREECOMPONENT ANALYTICAL MODEL}

Abstract

The article presents the solution of accumulation and efficiency of human capital using in conditions of regional economy's digitalization. The potentially new thee-component method of human capital analysis "SourceMechanism-Result" allows to estimate the balance between the results of human capital using and its reproduction processes in digitalization of the economy conditions. The approbation of the authors conceptual method is implemented with using such tools, like: index method, regression and cluster econometric analysis. The result of the investigation is revealing of key catalysts and inhibitors of effective human capital using processes in the regions of southern Russia.

Keywords: human capital, digitalization of economy, regions of the South of Russia, regional economy, balance of development, economic results, economic processes of integration, index of human development, actor of an economic system.

References

1. Becker G.S. Investment in Human Capital: A Theoretical Analysis//Journal of Political Economy, Vol.70, No.5, Part 2, 1962, pp.9-49

2. Shultz T. Human Capital in the International Encyclopedia of the Social Sciences. - N.Y., 1968. - Vol. 6

3. Thurow L. (1970). Investment in Human Capital, Belmont. P. 1-15, 104.

4. Blaug, M. ( 1970). An Introduction to the Economics of Education. L. P. 19

5. Machlup F. (1984). The Economics of Information and Human Capital. Princeton. 201-203 P.

6. Edvison L., Meloun M. Intellektual'nyj kapital. Opredelenie istinnoj stoimosti kompanii // Novaya postindustrial'naya volna na Zapade. Antologiya. - M.: Academia, 1999.

7. Zabelina O.V., Kozlova T.M., Romanyuk A.V. CHelovecheskij kapital regiona: problemy sushchnosti, struk-tury i ocenki // Statistika i ekonomika. 2013. №4.

8. Grachev S. A. Ocenka velichiny chelovecheskogo kapitala regionov na osnove mnogokriterial'nogo pod-hoda // Voprosy upravleniya. 2018. №2 (32). P. 46 - 53.

9. Anichin V.L., Dorofeev A.F., Vashchejkina YU.YU. Stoimostnaya ocenka chelovecheskogo kapitala // Nauchnye vedomosti Belgorodskogo gosudarstvennogo universiteta. Seriya: Ekonomika. Informatika. 2017. T. 43. № 16 (265). P. 90 - 96.

10. Saharova O.N. Indeks razvitiya chelovecheskogo potenciala: mesto Rossii v sovremennom mire // Vest-nik TIUiE. 2014. №1 (19). P. 16 - 20.

11. Pitajkina I.A., Vlazneva S.A. Formirovanie novogo kachestva chelovecheskogo kapitala v usloviyah cifrovoj ekonomiki // Voprosy ekonomiki i prava. 2018. №7.S. 39 - 44.

12. SHibaeva N.A., Evdokimova O.V. Povyshenie funkcional'noj aktivnosti chelovecheskogo kapitala v cifrovoj ekonomike // Upravlenie innovaciyami / materialy mezhdunar. nauch.-praktich. konf. No-vocherkassk: Izd-vo YURGPU (NPI) im. M.I. Platova, 2018. P. 71 - 76.

13. Dyatlov S.A., Dobrohotov M.A. Formy realizacii chelovecheskogo kapitala v cifrovoj ekonomike // Izvestiya SanktPeterburgskogo gosudarstvennogo ekonomicheskogo universiteta. 2018. № 4. P. 25 - 28.

14. Kel'chevskaya N.R., SHirinkina E.V. Osobennosti upravleniya chelovecheskim kapitalom na predpriyatiyah v usloviyah cifrovoj ekonomiki // Innovacii v menedzhmente. 2018. № 4(18). P. 24 - 31. 